UDC 338.1

\title{
Scenarios of the Polish economy dynamics in 2017-2022 on the Ramsey type model basis
}

\author{
Valeriya A. Chychuryna ${ }^{1}$, Nikolay N. Olenev ${ }^{2,3}$ \\ ${ }^{1}$ European University in Warsaw \\ 22 Białostocka St., Warsaw, 03-741, Republic of Poland \\ ${ }^{2}$ Dorodnicyn Computing Centre, FRC CSC RAS \\ 40 Vavilov St., Moscow, 119333, Russian Federation \\ ${ }^{3}$ Peoples' Friendship University of Russia (RUDN University) \\ 6 Miklukho-Maklaya St., Moscow, 117198, Russian Federation
}

\begin{abstract}
The article contains a methodology of identification of the dynamic Ramsey model for the Polish economy. It includes two different scenarios of the development of the Polish economy for five years (2017-2022) and the comparison of the forecasts made on their basis. The first scenario is built using the model parameters estimated basing on the data for the period 1991-2016. The second scenario considers a more recent period (2010-2016), which is picked according to a hypothesis that the statistical data of this period describing the labor force dynamics shows its trend more representatively. The method of model identification is based on evaluating the proximity between the calculated and statistical time series of macroeconomic indicators (output, consumption, investment, export, import). The GDP and investments volumes are predicted for the five years' period and the visualization of the forecasted trend is made for the both identified models.
\end{abstract}

Keywords: Ramsey model; Polish economy; dynamic model; parameter identification; computer simulation; economy forecasting; forecast scenarios; gross domestic product; investments

\section{Introduction}

Effective forecasting of the economy is one of the most urgent scientific, political and social problems. There are several reasons for the negative affect on the accuracy of economic forecasts, in addition to the basic problem of uncertainty. Among the first ones the increased complexity of the economic system and the feedback loop (Shaw, 2017; Clements, Hendry, 2002) are traditionally named. An effective means of decreasing the feedback loop effect is to build several variants of forecast with a graded probability measure.

In its turn, the increased complexity led to the failure of traditional theory of economic forecasting (Joutz, 2006). In terms of development of scientific researches in this field this meant moving from linear models and unconditional forecasting to dynamic models, based on time series approximation. 
The dynamic model of the economy, in which production is defined by the neoclassical production function, and the production factors (labor and capital) are changing due to the given differential equations, was called the Ramsey model in honor of the fundamental work of Frank Plampton Ramsey (Ramsey, 1928), in which the problem of the optimal level of savings in a closed economy was considered. This simplest dynamic model of the economy was used by many scientists in the theoretical studies of the economy, both before and after Ramsey (Moiseev, 1975), Robert Solow's great contribution to the study of the economic growth with the help of this model and the production function of Cobb - Douglas (Solow, 1956) resulted in the fact that this version was called in his honor 'the Solow model' (some its modification was called 'the Solow - Swan model').

In this paper we consider two forecast options of the Polish economy development designed basing on the simplest dynamic model for an open economy. The dynamic model of the economy proposed in (Olenev, Pechenkin, 2007) and used in the paper is called the Ramsey type model, since a great attention in this work is paid to determining the share of accumulation in the economy. In order to make the forecast possible, the problem of identifying the external parameters of the whole model is solved.

The identification of the model (Olenev, Pechenkin, 2007) made it possible to determine the reasons for the economic growth in the 2000s in Russia. The growth was caused by the return of the production assets excluded from the production process during the unsuccessful experiments of the 1990s, and involved again after the default of 1998. This interpretation of the identification results allowed to calculate it at the end of 2006 that in 2008 the problems caused by the depletion of the reserve production assets were going to arise in the Russian economy. Unfortunately, the forecast (Olenev, Pechenkin, 2007) was not heard in time, so the relevant measures were not taken in advance. This resulted in the crisis of 2008, which was first explained by the global financial crisis that happened that year. Only ten years later it was officially recognized that the causes of the Russian crisis were internal.

Here we consider the problem of building several forecast scenarios that reflect the variants of the future economy dynamics in the most accurate way. We build a basic scenario according to the obtained external parameters of the dynamic Ramsey model for the Polish economy. Using the original numerical-analytical method, we find all the external parameters of the model, including parameters of a homogeneous production function with a constant elasticity of substitution. The method includes the evaluation of the proximity between the model trajectories calculated with the given parameters and their statistical analogs: this means the real historical time series of macroeconomic indicators, such as the gross domestic product (GDP) $Y$, investment $J$ and other components of the balance of GDP usage. Further a choice of such a set of parameters, for which the compared trajectories are closest to each other basing on the criterion of the Theil inequality, is made.

Then we design an optimistic scenario, taking into account the period 2010-2016, which reflects the nowadays trend of labor force in Poland most representatively. We reidentify the parameters of the model, investigate the accuracy of the model basing on the Theil criterion. 
And finally we calculate the future values of gross domestic product and investments according to both scenarios, make a comparison and visualization, which lets us make an analytical interpretation of the obtained results.

\section{Model description}

In order to describe the Polish economy model, we consider a Ramsey type dynamic model (Olenev, Pechenkin, 2007; Kamenev, Olenev, 2015) of a kind

$$
Y(t)=Y_{0}\left[a\left(L(t) / L_{0}\right)^{-b}+(1-a)\left(K(t) / K_{0}\right)^{-b}\right]^{-1 / b},
$$

where $Y$ is gross domestic product, $L$ is amount of people involved in the economy, $K$ is amount of capital involved in the economy. $Y_{0}, L_{0}, K_{0}$ are initial conditions for the functions $Y, L, K$ at the chosen moment of time (year), given at constant 2010 prices. According to their economic sense, parameters $a, b$ are restricted by the relations

$$
a \in(0,1), b>-1 \text {. }
$$

Then, basing on the statistical data (The United Nations Statistics Division, 2018; International Labour Organization, 2018), we make the next assumptions about the labor $L$ and investments $J$

$$
\begin{aligned}
& \frac{d L}{d t}=\gamma L, L(0)=L_{0}, \\
& \frac{d K}{d t}=J(t)-\mu K, K(0)=K_{0},
\end{aligned}
$$

where $J$ is gross capital formation, $\gamma>0, \mu$ are parameters of the model.

\section{Basic model scenario}

In order to build the basic forecast of the Polish economy development, we consider the time period from 1900 till 2016. Further everywhere in this section it is assumed that $t=0$ corresponds to 1990 . Then, if the number of the year is denoted as $n$, the internal time is $t=n-1990$.

Formula (1) shows that the gross domestic product $Y(t)$ is determined by a homogeneous production function with a constant elasticity of substitution.

The initial conditions for the three functions $L, K, Y$ are

$$
L_{0}=17.438, K_{0}=635.507 \eta, Y_{0}=635.507
$$

and are taken as the values for 1990 from (Solow, 1956). The values of the function $L$ are given in millions of people, of the functions $K, Y-$ in billions of zlotys.

Let us consider the graph of the function $L_{\text {stat }}$ (Figure 1). The corresponding values from (Solow, 1956) are represented by dots in this graph. By using a leastsquares method to find a fit to a list of data of values $L_{\text {stat }}$ we obtain the equality

$$
L(t)=17.438 e^{-0.001 t} .
$$




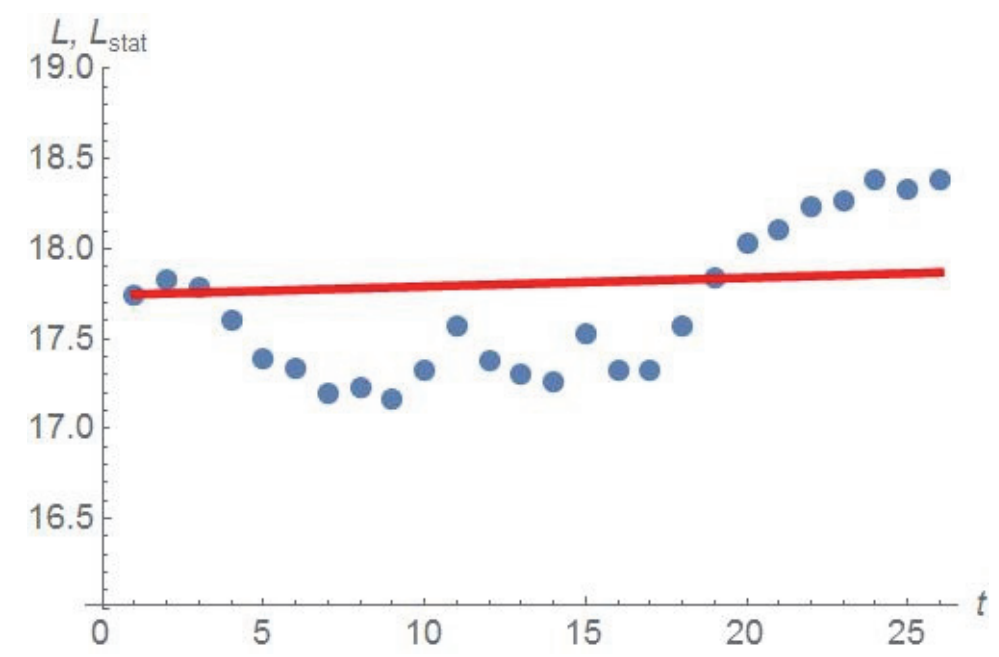

Figure 1. Points represent values of $\boldsymbol{L}_{\text {stat }}$ and the straight line is defined by the equation (5)

Source: own elaboration

Functions $J(t), Y(t)$ are connected to each other by the relation

$$
J(t)=\frac{\sigma}{\mathrm{p}(t)} * Y(t)
$$

where the coefficient $\frac{\sigma}{\mathrm{p}(t)}$ is defined from the tables (The United Nations Statistics Division, 2018), $\sigma$ is the average value of the ratio of investments in a given year at current prices to GDP in the same year at current prices, and $\mathrm{p}(t)$ is equal to $\frac{\mathrm{p} J(t)}{\mathrm{p} Y(t)}$; the numerator of this fraction is the ratio of the investments at current prices to its value at constant 2010 prices and the denominator is the same ratio of GDP.

The graph of the coefficient $\frac{\sigma}{\mathrm{p}(t)}$ appropriately to years is depicted on Figure 2. The corresponding values of the function $\mathrm{p}(t)$ are calculated basing on the statistical data (The United Nations Statistics Division, 2018), and coefficient $\sigma$ is defined as the average value $\sigma_{a v}$; then we use the least squares method to build a line

$$
\frac{\sigma}{\mathrm{p}(t)}=0.179+0.002 t
$$

Taking into account the equality (7), we rewrite the relation (6) in the form

$$
J(t)=(0.179+0.002 t) * Y(t) \text {. }
$$

We solve differential equation (3) as a difference equation. Using the Euler method with a time step of 1 year, as well as taking into account the initial conditions (4) and relation (5) we obtain

$$
\mathcal{K}(t+1)=(1-\mu) \mathcal{K}(t)+(104.402+1.476 t)\left(a e^{0.0003 b}+(1-a) e^{6.454 b}\left(\frac{\mathcal{K}(t)}{\eta}\right)^{-b}\right)^{-1 / b},
$$

where $t=5$. 


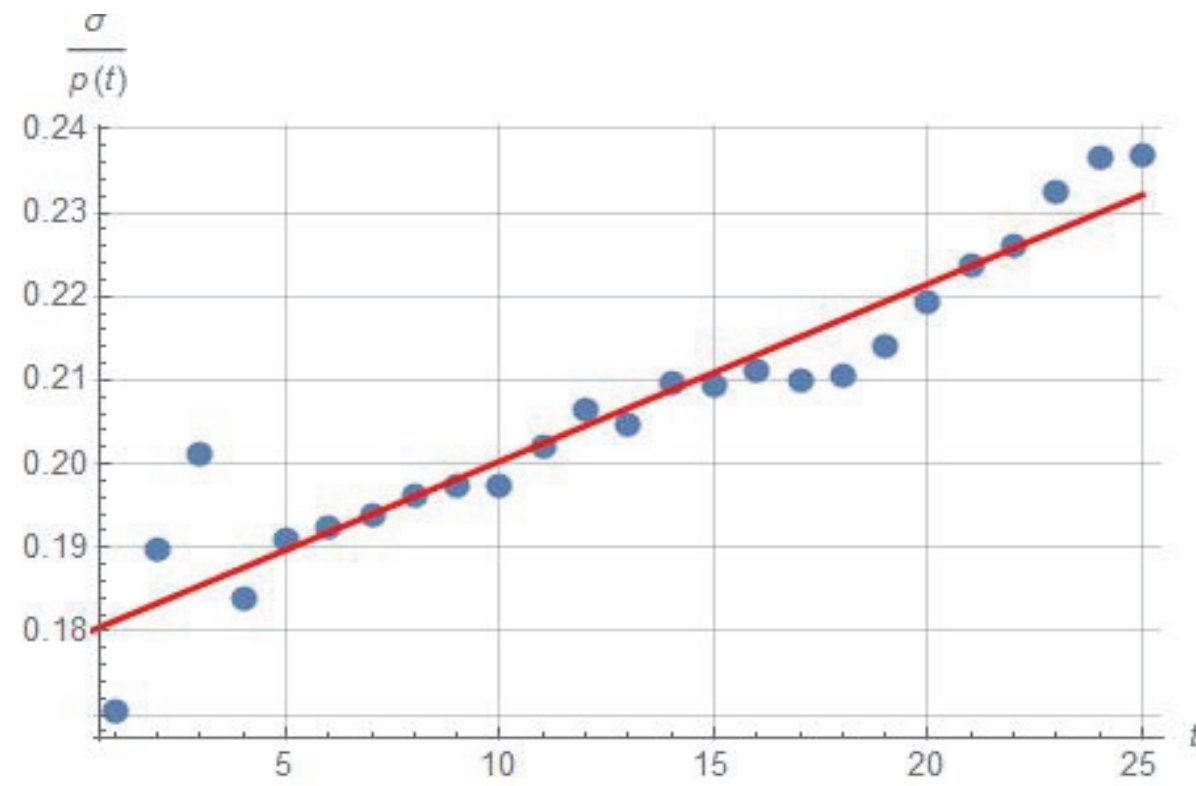

Figure 2. Points represent values of $\frac{\sigma}{\mathbf{p}(t)}$, the straight line is defined by the equation (7)

Source: own elaboration.

Substituting (4) and (9) into (1), we obtain a recurrence relation for the function $Y$. formula

Using the method outlined in the paper (Ramsey, 1928), according to the

$$
U(X, Y)=1-\sqrt{\frac{\sum_{t=1}^{n}\left(X_{t}-Y_{t}\right)^{2}}{\sum_{t=1}^{n} X_{t}^{2}+\sum_{t=1}^{n} Y_{t}^{2}}}
$$

we build the coefficient of proximity $U_{Y}$ for the function $Y$, and then, considering the formula (7), we build the coefficient of proximity $U_{J}$ for the function $J$. Then we build a closure (Olenev, Pechenkin, 2007) for the product of functions $U_{Y} U_{J}$ and find its maximum on the following intervals of variation of the parameters

$$
a \in(0.1,1), b \in(0.1,1), \mu \in(0.01,0.09), \eta \in(0.1,1.5) .
$$

Such intervals are chosen on the basis of economic considerations (Olenev, Pechenkin, 2007).

Carrying out the numerical analysis of the values of parameters on the indicated intervals using the method of enumeration with the step of 0.1 for the parameter $a$, with the step of 0.1 for the parameter $b$, with the step of 0.01 for the parameter $\mu$, with the step of $0.1 \mathrm{f}$ or the parameter $\eta$, we obtain the set of parameters

$$
(a, b, \mu, \eta)=(0.3,0.3,0.05,1.3)
$$

under which the product $U_{Y} U_{J}$ take the value 0.9124 . 
Let us draw graphics for the functions $Y$ and $Y_{\text {stat }}$ (Figure 3) and $J$ and $J_{\text {stat }}$ (Figure 4).

- $Y_{\text {stat }} \bullet Y$

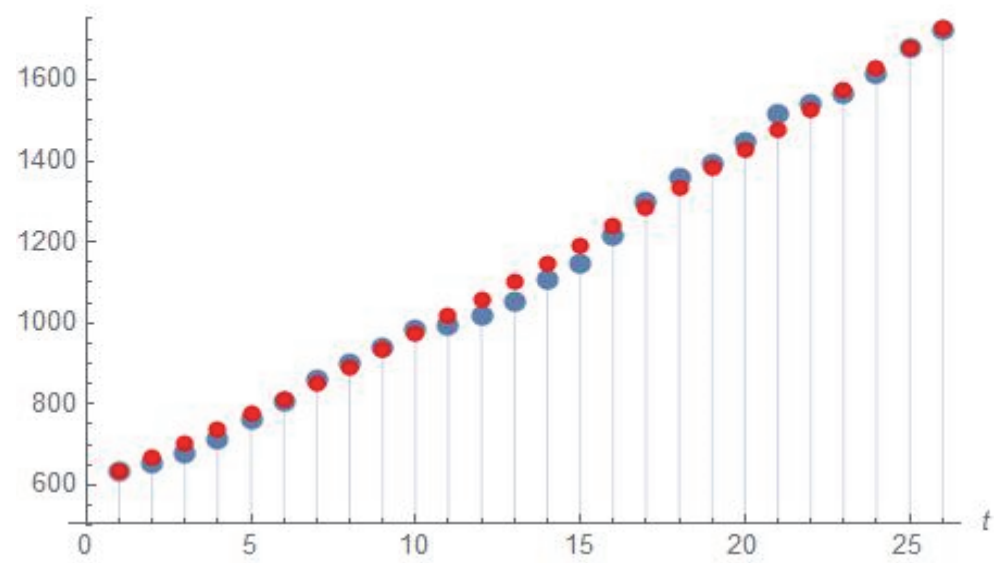

Figure 3. Comparison of calculated $Y$ and statistical $\boldsymbol{Y}_{\text {stat }}$ values of GDP $\bullet J_{\text {stat }} \bullet \mathrm{J}$

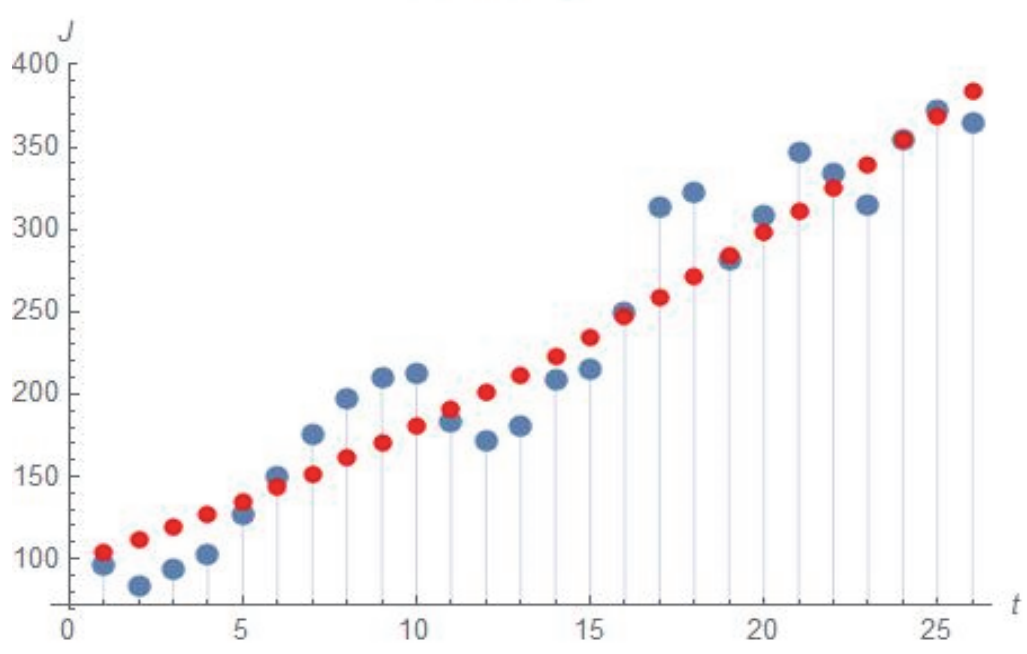

Figure 4. Comparison of calculated $J$ and statistical $\boldsymbol{J}_{\text {stat }}$ values of investment

Source: own elaboration.

Assuming that the parameters $(a, b, \mu, \eta)$ keep their values for the next 5 years, we make a forecast for 2017-2021. In order to do this, we calculate the values of the functions $Y$ and $J$ for 2017-2021 (Tables 1 and 2).

Table 1

The values of the function $Y$ for 2017-2021

\begin{tabular}{lccccc}
\hline Year & 2017 & 2018 & 2019 & 2020 & 2021 \\
$\mathbf{Y}_{\text {prog }}$ & 1779.01 & 1830.23 & 1881.66 & 1933.28 & 1985.05 \\
\hline
\end{tabular}


The values of the function $J$ for 2017-2021

\begin{tabular}{lccccc}
\hline Year & 2017 & 2018 & 2019 & 2020 & 2021 \\
$\mathbf{Y}_{\text {prog }}$ & 399.695 & 415.455 & 431.501 & 447.828 & 464.430 \\
\hline
\end{tabular}

In order to show visually how the situation is going to change according to this scenario, we will draw the graphs of the obtained function values of $Y$ and $J$ for 2017-2021 as the continuation of the graphs of the values of these functions for 1991-2016 (Figures 5 and 6) showing the beginning part of the trend.

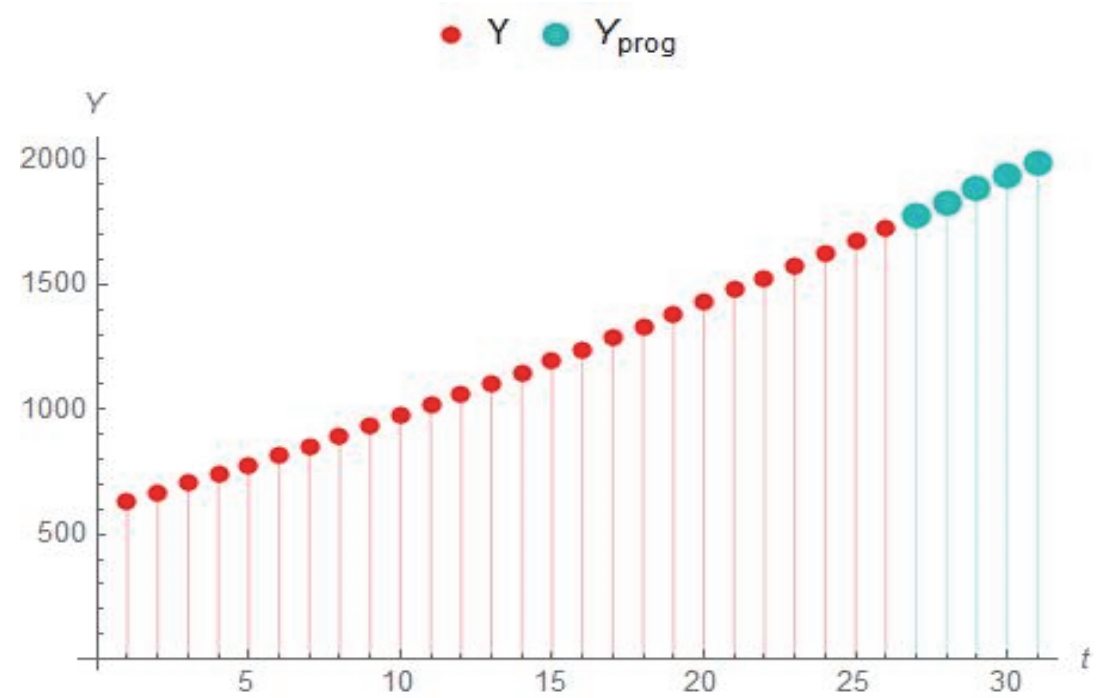

Figure 5. The forecast of GDP dynamics for 2016-2020 according to the first scenario Source: own elaboration.

$$
\text { - J } J_{\text {prog }}
$$

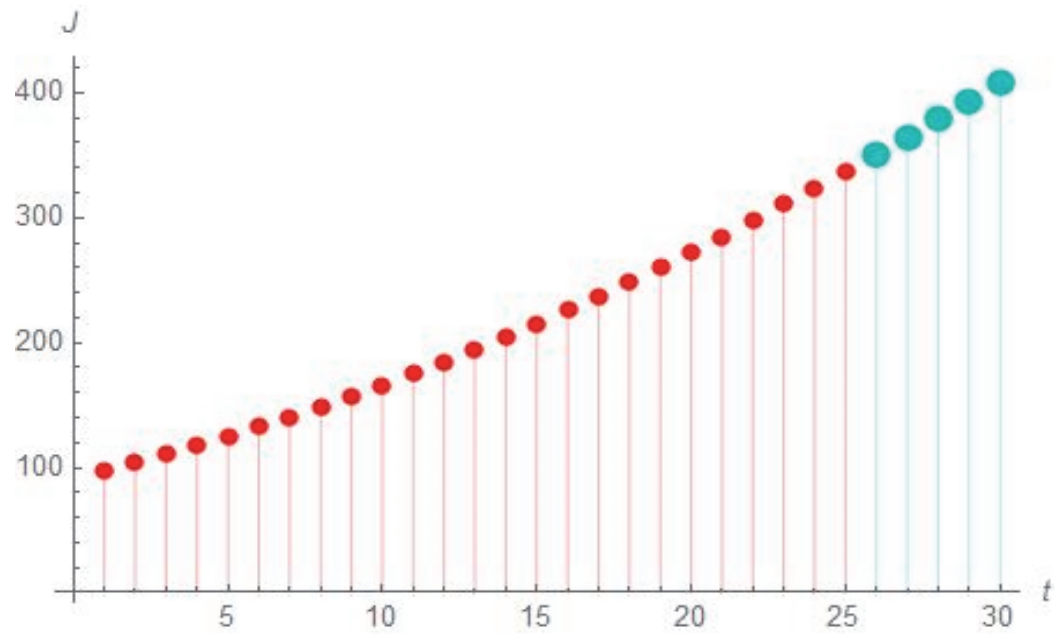

Figure 6. The forecast of investment dynamics for 2016-2020 according to the first scenario Source: own elaboration. 


\section{Alternative model scenario}

One of the crucial functions of economic modeling is to present several scenarios of forecasts considering different changes in separate parameters. This function lets the decision-makers observe the situation from different points of view, estimate the alternative costs of each direction that can hypothetically be chosen.

In our case, observing the data series of the parameter $L$ (the number of people involved in an economy) on the Figure 1, we can see, that the nowadays trend has its beginning in the twentieth point, which corresponds to the year 2010.

The declines in the amount of economically active people can be easily explained, if we take a look at the time period which they belong to. This time period corresponds to the process of Polish integration to EU, which caused the significant outflow of workers from Poland.

So, assuming that till 2010 this process has burnt out and the further curve shows us the actual trend of the labor force dynamics, we look for the function to define the function $L$ between the years 2010-2016. In this case, if the number of the year is denoted as $n$, the internal time is $t=n-2010$.

In order to make a forecast based on this shorter period, we have to reidentify the model according to the statistical data, related to this period. If we take year 2010 as the starting point, the initial conditions for the three functions $L, K, Y$ are

$$
L_{0}=18.036, K_{0}=1445.297 \eta, Y_{0}=1445.297
$$

also taken from (The United Nations Statistics Division, 2018; International Labour Organization, 2018), like in the first case.

Basing on the statistical data, we build a graphic of the coefficient $\frac{\sigma}{\mathrm{p}(t)}$, which is defined from the tables (The United Nations Statistics Division, 2018), during the 2010-2016 period. Then we find a function, which approximates the obtained curve best. In our case, this function is next

$$
\frac{\sigma}{\mathrm{p}(t)}=0.209+0.003 t-0.003 \sin t \text {. }
$$

Visually the way this function approximates $\frac{\sigma}{\mathrm{p}(t)}$ is shown on the Figure 7 .

We apply the same method to design the function, approximating the $L$ function. The obtained function is the core of this forecast scenario, and, basing on the statistics (International Labour Organization, 2018), we get the next its form:

$$
\mathcal{L}(t)=17.966+0.193 t-0.049+0.004 t^{3}-0.093 \sin t .
$$

Like in the first case, we solve differential equation (3) as a difference equation. Using the Euler method and taking a time step of 1 year, as well as taking into account the initial conditions (4) and relation (5) we obtain

$$
\begin{gathered}
\mathcal{K}(t+1)=\mathcal{K}(t)-\mu \mathcal{K}(t)+(302.226+3.983 t-3.887 \sin t) \times \\
\times\left(a\left(0.996+0.011 t-0.003 t^{2}+0.0002 t^{3}-0.005 \sin t\right)^{-b}+\right. \\
+(1-a) e^{\left.7.276 b\left(\frac{\mathcal{K}(t)}{\eta}\right)^{-b}\right)^{-\frac{1}{b}}}
\end{gathered}
$$

where $t=5$. 


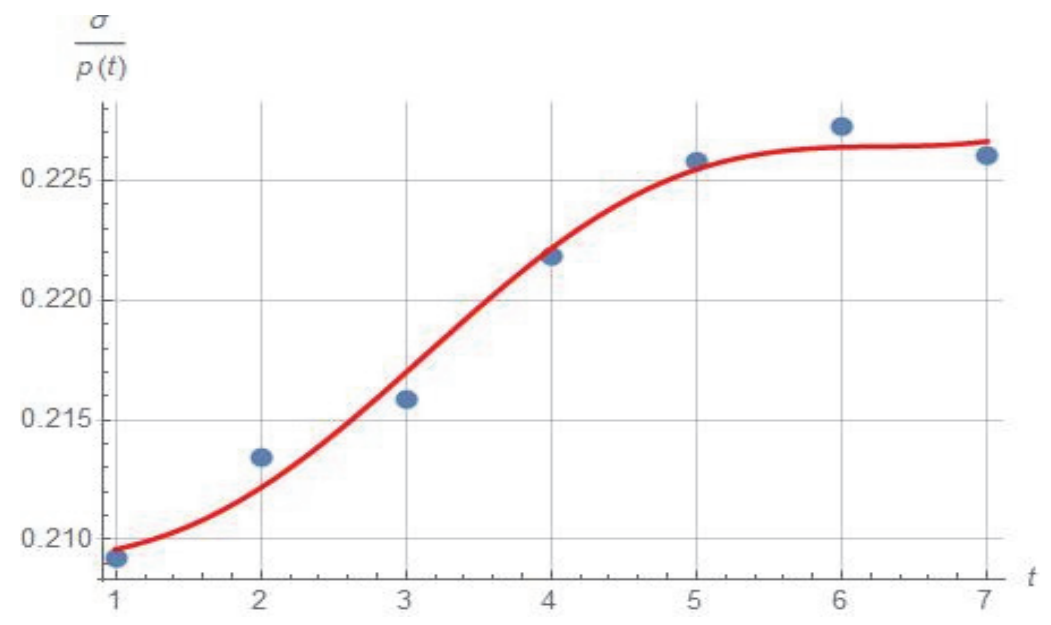

Figure 7. Points represent values of $\frac{\sigma}{\mathbf{p}(t)}$, the straight line is defined by the equation (12)

Source: own elaboration.

Substituting (11) and (14) into (1), we obtain a recurrence relation for the function $Y$.

We are using the same method, outlined in the paper (Olenev, Pechenkin, 2007), as it was done in the first case, to build a closure (Olenev, Pechenkin, 2007) for the product of functions $U_{Y} U_{J}$ and find its maximum on the following intervals of variation of the parameters

$$
a \in(0.1,1), b \in(0.1,1), \mu \in(0.01,0.09), \eta \in(0.1,1.5) \text {. }
$$

Such intervals are chosen on the basis of economic considerations (Olenev, Pechenkin, 2007).

Carrying out the numerical analysis of the values of parameters on the indicated intervals using the method of enumeration with the step of 0.05 for the parameter $a$, with the step of 0.05 for the parameter $b$, with the step of 0.005 for the parameter $\mu$, with the step of 0.05 for the parameter $\eta$, we obtain the set of parameters

$$
(a, b, \mu, \eta)=(0.4,0.9,0.09,1.5)
$$

under which the product $U_{Y} U_{J}$ take the value 0.953553 .

Let us draw graphics for the functions $Y$ and $Y_{\text {stat }}$ (Figure 8) and $J$ and $J_{\text {stat }}$ (Figure 9).

Assuming that the parameters $(a, b, \mu, \eta)$ keep their values for the next 5 years, we make a forecast for 2017-2021. In order to do this, we calculate the values of the functions $Y$ and $J$ for 2017-2021 (Tables 3 and 4).

In order to show visually how the situation is going to change according to this scenario, we will draw the graphs of the obtained function values of $Y$ and $J$ for 2017-2021 as the continuation of the graphs of the values of these functions for 1991-2016 (Figures 10 and 11) showing the beginning part of the trend. 

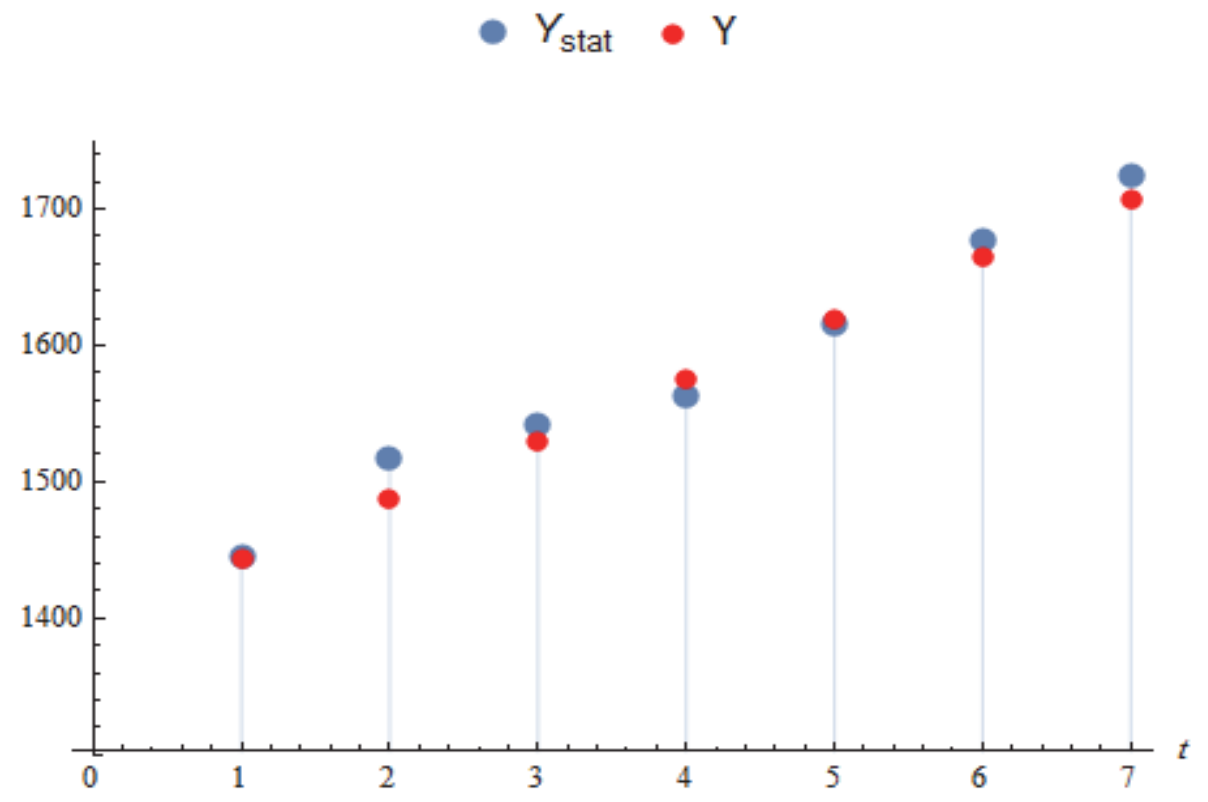

Figure 8. Comparison of calculated $Y$ and statistical $Y_{\text {stat }}$ values of investment according to the second scenario

Source: own elaboration.
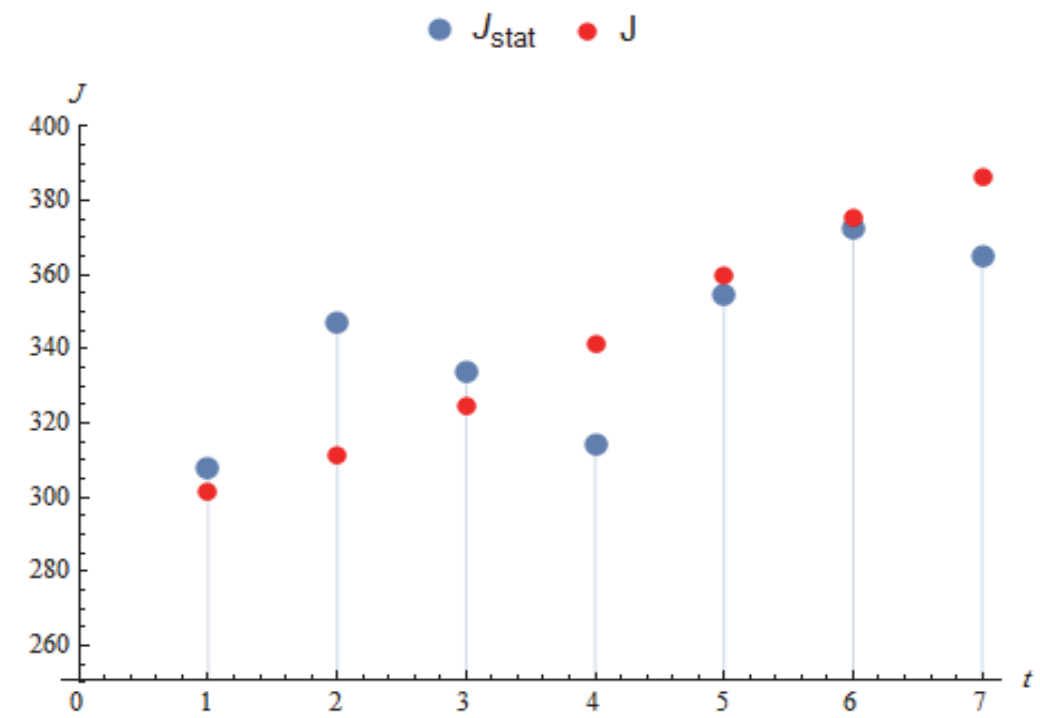

Figure 9. Comparison of calculated $J$ and statistical $\boldsymbol{J}_{\text {stat }}$ values of investment according to the second scenario

Source: own elaboration.

The values of the function $Y$ for 2017-2021

\begin{tabular}{cccccc}
\hline Year & 2017 & 2018 & 2019 & 2020 & 2021 \\
$\mathbf{Y}_{\text {prog }}$ & 1749.11 & 1796.26 & 1852.80 & 1920.17 & 1997.20 \\
\hline
\end{tabular}


The values of the function $J$ for 2017-2021

\begin{tabular}{lccccc}
\hline Year & 2017 & 2018 & 2019 & 2020 & 2021 \\
$\mathbf{Y}_{\text {prog }}$ & 396.408 & 410.439 & 431.341 & 457.255 & 483.552 \\
\hline
\end{tabular}

$$
\bullet Y \bullet Y_{\text {prog }}
$$

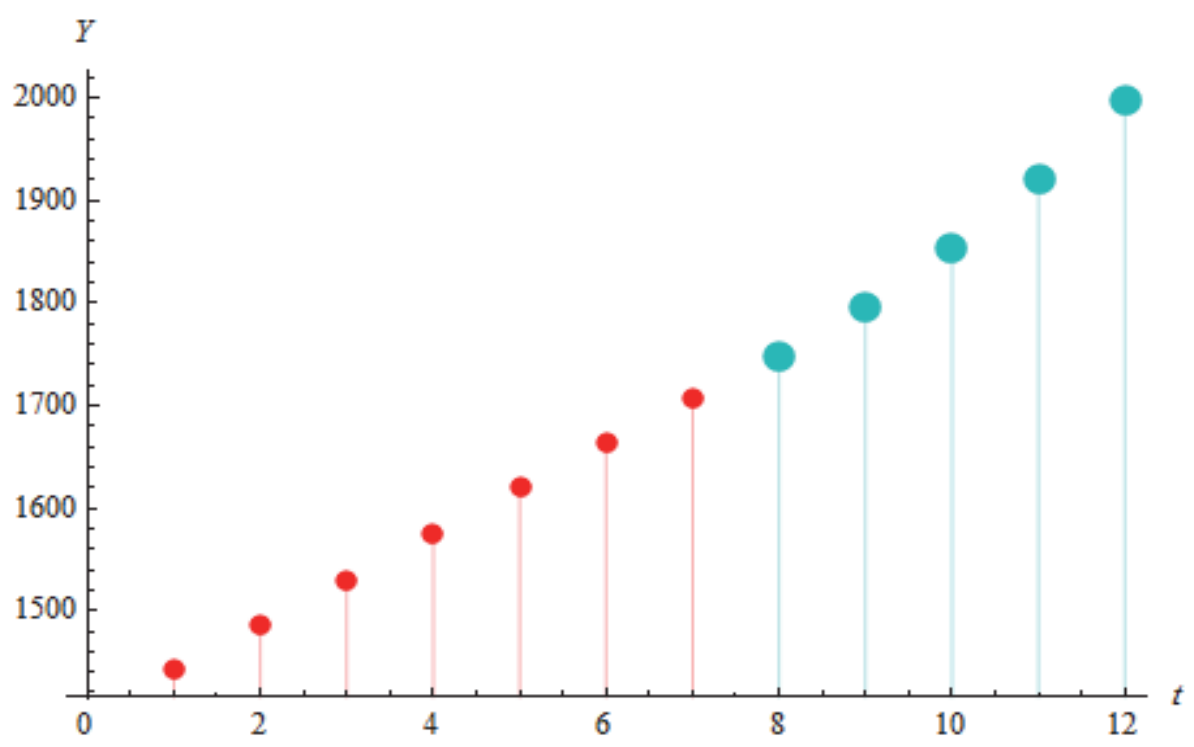

Figure 10. The forecast of GDP dynamics for 2016-2020 according to the second scenario Source: own elaboration.

$$
\text { - J } J_{\text {prog }}
$$

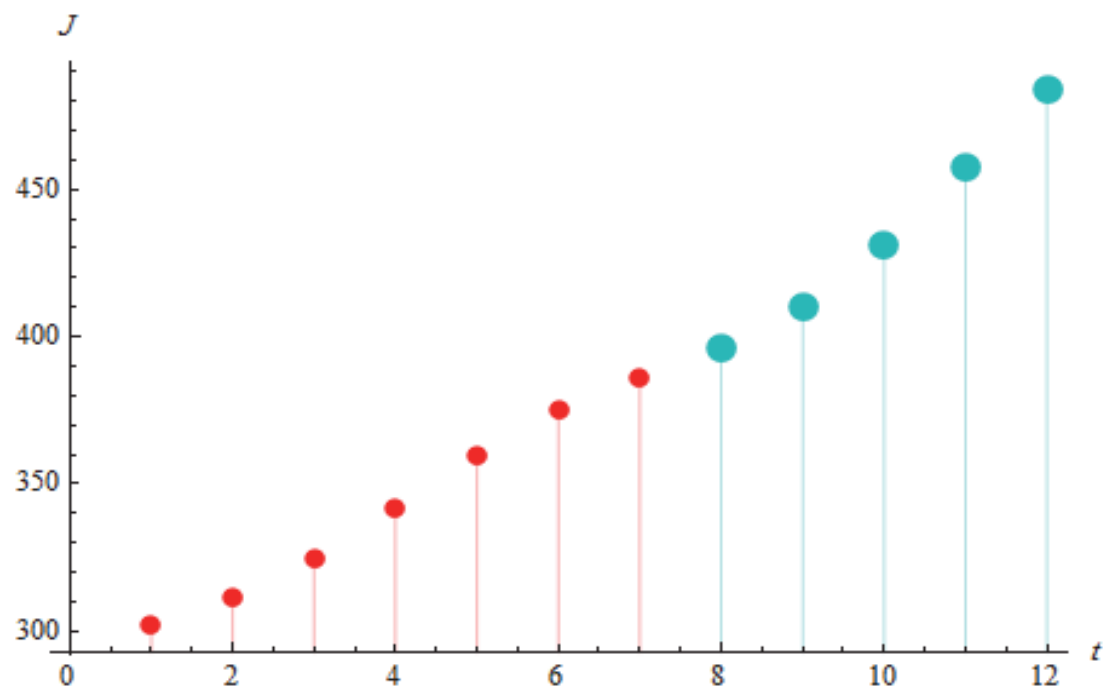

Figure 11. The forecast of investments dynamics for 2016-2020 according to the second scenario Source: own elaboration. 


\section{Conclusion}

The main results obtained during the study of the paper are next:

Identification values of the parameters for the Ramsey type model (1)-(3), got basing on the data of Polish economy of 1991-2016 in the first case and on the same statistics of 2010-2016 in the second one, are different. Their values are next:

- first scenario: $a=0.3, b=0.3, \mu=0.05, \eta=1.3$;

- second scenario: $a=0.4, b=0.9, \mu=0.09, \eta=1.5$.

The forecasted values of gross domestic product and investments show different dynamics. According to the first scenario, where we assume, that the trend of the future economy parameters changes will stay the same during the forecasted period, we get the next results:

- forecasted gross domestic product in 2021 - 1997.20 billions of zlotys, average annual increment $-3.37 \%$;

- forecasted investments in $2021-483.552$ billions of zlotys, average annual increment $-0.5 \%$.

According to the second scenario, where we assume, that the trend of the future economy parameters changes is conditioned by the changes in labor force during 2010-2016, we get the next results:

- forecasted gross domestic product in 2021 - 1985.05 billions of zlotys, average annual increment $-2.78 \%$;

- forecasted investments in $2021-464.430$ billions of zlotys, average annual increment $-3.8 \%$.

This leads us to the conclusion, that considering the whole period 1990-2016 when identifying model, we get a higher forecasted value of GDP of year 2021 by $0.6 \%$ than considering the period 2010-2016. At the same time, we get a significantly higher rate of the investments growth ( 0.59 percentage points).

Acknowledgements and Funding. This work was partly supported by the Russian Science Foundation, Project No. 14-11-00432.

\section{References}

Clements M.P., Hendry D.F. (2002). An Overview of Economic Forecasting. A Companion to Economic Forecasting (Chapter 1). Oxford, Blackwells.

International Labour Organization. (2018, February 13). ILOSTAT database. Retrieved from https://data.worldbank.org/indicator/SL.TLF.TOTL.IN?locations=PL

Joutz F.L. (2006). Econometric Forecasting Models. The Middle Atlantic Actuarial Club.

Kamenev G.K., Olenev N.N. (2015). Study of the Russian Economy's Identification and Forecast Stability Using a Ramsey Type Model. Mathematical Models and Computer Simulations, (2), 79-189.

Moiseev N.N. (1975). Prostejshie matematicheskie modeli jekonomicheskogo rosta [Simplest mathematical models of economic growth]. Matematika, kibernetika. Moscow. 66 p. (In Russ.)

Olenev N.N. (2015). A study of structural changes influence on Russian economy. Bulletin of Peoples' Friendship University of Russia. Series: Economics, (1), 150-157.

Olenev N.N., Pechenkin R.V., Chernetsov A.M. (2007). Parallel'noe programmirovanie $v$ MATLAB i ego prilozhenija [Parallel MATLAB programming and its applications]. Moscow, VC RAN Publ. 120 p. (In Russ.) 
Ramsey F.P. (1928). A Mathematical Theory of Saving. The Economic Journal, 38(1520), 543-559.

Shaw A. (2017). Why economic forecasting has always been a flawed science. The Guardian. Retrieved from https://www.theguardian.com/money/2017/sep/02/economic-forecastingflawed-science-data

Solow R.M. (1956). A Contribution to the Theory of Economic Growth. The Quarterly Journal of Economics, (1), 65-94.

The United Nations Statistics Division. (2018, February 13). National Accounts Main Aggregates Data. Retrieved from https://unstats.un.org/unsd/snaama/dnllist.asp

\title{
Article history:
}

Received: 24 December 2018

Revised: 15 February 2019

Accepted: 02 April 2019

\section{For citation:}

Chychuryna V.A., Olenev N.N. (2019). Scenarios of the Polish economy dynamics in 2017-2022 on the Ramsey type model basis. RUDN Journal of Economics, 27(2), 235-248. http://dx.doi.org/10.22363/2313-2329-2019-27-2-235-248

\section{Bio notes:}

Valeriya A. Chychuryna, PhD Student, European University in Warsaw. E-mail: takotsubocard@gmail.com

Nikolay N. Olenev, Cand. Sc. (Phys. and Math.), Docent, Leading Researcher, Dorodnicyn Computing Centre - Federal Research Center of Computer Science and Control under the Russian Academy of Sciences; Associated Professor, Nikol'skii Mathematical Institute, Peoples' Friendship University of Russia (RUDN University). E-mail: nolenev@mail.ru

\section{Сценарии развития польской экономики в 2017-2022 гг. на базе модели типа Рамсея}

\author{
В.А. Чичурина ${ }^{1}$, Н.Н. Оленев ${ }^{2,3}$ \\ ${ }^{1}$ Европейский университет в Варшаве \\ Республика Польша, 03-741, Варшава, ул. Белосток, 22 \\ ${ }^{2}$ Вычислительный центр имени А.А. Дородницына ФИЦ ИУ РАН \\ Российская Федерация, 119991, Москва, ул. Вавилова, 42 \\ ${ }^{3}$ Российский университет дружбы народов \\ Российская Федерация, 117198, Москва, ул. Миклухо-Маклая, 6
}

Статья содержит методологию определения параметров динамической модели типа Рамсея для польской экономики. Приводятся два различных сценария развития польской экономики на пять лет (2017-2022 гг.) и сопоставляются между собой прогнозы, сделанные на их основе. Первый сценарий строится с использованием параметров модели, рассчитанных на основе статистических данных за период 1991-2016 гг. Второй сценарий основывается на использовании данных за более поздний период (2010-2016 гг.), который выбран согласно гипотезе о том, что статистические данные 
этого периода, описывающие динамику роста рабочей силы, более репрезентативны с точки зрения текущей тенденции развития экономики. Метод идентификации модели базируется на оценке близости между расчетным и статистическим временным рядом макроэкономических показателей (выпуск, потребление, инвестиции, экспорт, импорт). Для объема ВВП и инвестиций составлен прогноз на пятилетний период, а также построена визуализация динамики прогнозируемых показателей.

Ключевые слова: модель Рамсея; польская экономика; динамическая модель; идентификация параметров; компьютерная симуляция; экономическое прогнозирование; прогнозные сценарии; выпуск; инвестиции

Благодарности и финансирование. Статья подготовлена при финансовой поддержке РНФ, проект № 14-11-00432.

\section{История статьи:}

Дата поступления в редакцию: 24 декабря 2018

Дата проверки: 15 февраля 2019

Дата принятия к печати: 02 апреля 2019

\section{Для цитирования:}

Chychuryna V.A., Olenev N.N. Scenarios of the Polish economy dynamics in 2017-2022 on the Ramsey type model basis (Сценарии развития польской экономики в 2017-2022 гг. на базе модели типа Рамсея) // Вестник Российского университета дружбы народов. Серия: Экономика. 2019. Т. 27. № 2. С. 235-248. http://dx.doi.org/10.22363/2313-23292019-27-2-235-248

\section{Сведения об авторах:}

Чичурина Валерия Александровна - аспирант Европейского университета в Варшаве. E-mail: takotsubocard@gmail.com

Оленев Николай Николаевич - кандидат физико-математических наук, доцент, ведущий научный сотрудник Вычислительного центра имени А.А. Дородницына Федерального исследовательского центра «Информатика и управление» Российской академии наук; доцент Математического института имени С.М. Никольского Российского университета дружбы народов. E-mail: nolenev@mail.ru 